UDC: 27-36:929 Konstantin I Veliki

Радивој Радић

Оригиналан научни рад

Универзитет у Београду

примљено: 1. јун 2013

Филозофски факултет

прихваћено: 1. октобар 2013

rradic@f.bg.ac.rs

\title{
ДА ЛИ ЈЕ КОНСТАНТИН МИХАИЛОВИЋ ИЗ ОСТРОВИЦЕ ЗНАО ДА ЈЕ „КОНСТАНТИНОВА ДАРОВНИЦА“ ФАЛСИФИКАТ?*
}

Сажетак: У спису Константина Михаиловића из Островице, српског јаничара XV века, помиње се како је Константин Велики „уступио Рим светоме оцу папи Силвестру“. Реч је о једној легенди из V века по којој је римски првосвештеник наводно верски преобратио, крстио и чудесно исцелио цара. У знак захвалности Константин Велики је римског архипастира обдарио многим повластицама и даровима. На основу ове легенде у другој половини VIII века настао је фалсификат познат као „Константинова даровница (Constitutum Constantini)“, према којој је папа задобио власт над Римом, Италијом и читавом Западном Европом. У четвртој деценији XV века Никола Кузански и Лоренцо Вала су непобитно доказали да је посреди кривотворени документ. Очигледно да Константин Михаиловић, који је састављао своје дело на размеђу XV и XVI столећа, није знао да је приповест о Константину Великом и папи Силвестру у међувремену раскринкана као фалсификат.

Кључне речи: Константин Велики, папство, фалсификат, Константинова даровница (Constitutum Constantini), Константин Михаиловић, легенда.

Историја људског рода познаје велики број примера јуначких подвига и племенитих гестова појединаца и група, узвишених подухвата, задивљујућих прегнућа, али и велики број примера нечасних поступака, издаја, превара, фалсификата. Један од најпознатијих фалсификата, који се обавезно наводи у пригодним књигама, ${ }^{1}$ јесте тзв. „Константинова даровница (Constitutum Constantini)“. Овај документ има упориште у једној легенди која се први пут

\footnotetext{
* Овај рад је настао на пројекту Хришћанска култура на Балкану у средњем веку: Византијско иарство, Срби и Бугари од 9. до 15. века (бр. 177015), који финансира Министарство науке Републике Србије.

${ }^{1}$ На пример вид. B. I. Gutberlet, 50 najvećih laži i legendi svetske istorije (prev. D. Jokić), Beograd 2008, 5154.
} 
појављује у Риму, у V веку, и папи Силвестру (314-335) тенденциозно приписује преобраћење, крштење и чудесно оздрављење цара Константина I Великог (306337). Император је заузврат римског архипастира обдарио повластицама и даровима. Обиље „података“ из ове легенде пружило је потоњим кривотворитељима подесан и драгоцен материјал за састављање гласовитог документа. ${ }^{2}$

„Константинова даровница (Constitutum Constantini)“ је документ у облику конституције или повеље коју је наводно издао Константин Велики. У даровници цар у првом лицу најпре описује своју конверзију и признање вере (редови 1-155, Confessio), а потом следи завештање Римској цркви (редови 158-306, Donatio). ${ }^{3}$ Управо су тих три стотине редова латинског текста изазвали објављивање стотина научних радова о аутентичности „Константинове даровнице“, њеној првобитној намери и историјском утицају који је имала у каснијим епохама. ${ }^{4}$ Састављање овог документа датује се у период између 754. и 767,, а у сваком случају, како се наглашава у једном од најновијих радова, у раздобље пре 770. године. ${ }^{6}$

Како се може прочитати у даровници, Константин Велики је Светом Петру и његовим викарима, чији је универзални примат државноправно санкционисао, предао палату Латеран и знакове царског врховништва, док је римски клер добио

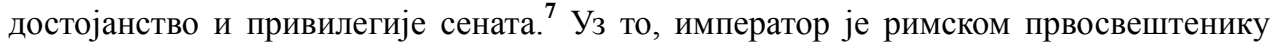
наводно поверио право првенства у односу на црквене поглаваре Александрије, Антиохије, Константинопоља и Јерусалима, као и судску власт над свештенством. Напуштајући Стари Рим и одлазећи у Нови Рим, односно Цариград, Константин Велики је римском архипастиру оставио престоницу на Тибру, Италију и целу Западну Европу. Штавише, папи Силвестру је била понуђена и владарска круна, али ју је он, наводно, учтиво одбио. ${ }^{8}$

Поједини истраживачи су с разлогом склони да у „Константиновој даровници“ виде и папски покушај да се умањи ауторитет Константинопоља. При том се истрајава на „чињеници“ да је Константин Велики папи Силвестру понудио царски ранг, али и на томе како се папа помирио са императоровим преласком из Рима у Константинопољ. Међутим, папство је као неку врсту надокнаде узело

\footnotetext{
${ }^{2}$ Velika povijest crkve (ur. H. Jedin, prev. V. Bajsić), II (Crkva Carstva poslije Konstanina Velikog), Zagreb 1995, 236; Ж. Дагрон, Цар и првосвештеник: студија о византијском „цезаропапизму“ (прев. В. Тријић), Београд 2001, 172, 282-284.

${ }^{3}$ Навешћемо два новија издања овог контроверзног документа: В. H. Furhman, Das Constitutum Constantini, Monumenta Germaniae Historica. Fontes Iuris Germanici Antiqui 10, Hanover 1968. и P. de Leo, Il Constitutum Constantini: Compilazione agiografica del sec. VIII, vol 1, Reggio Calabria 1974.

${ }^{4}$ За преглед најважније библиографије која се односи на Константинову даровницу вид. Dictionary of the Middle Ages (ed. J. R. Strayer), vol. IV (Croatia - Family Sagas, Icelandic), New York 1984, 259 (J. Van Engen) /у даљем тексту: DMA/; A. Kapsalis, The False-Donation of Constantine, Свети цар Константин и хришћанство (ур. Д. Бојовић), том I, Међународни научни скуп поводом 1700. годишњице Миланског едикта, 31. мај - 2. јун 2013. године, Ниш 2013, 91-107.

${ }^{5}$ DMA, IV, 1984, 258 (J. Van Engen).

${ }^{6}$ A. Kapsalis, False-Donation of Constantine, 91, 101, 107.

${ }^{7}$ Velika povijest crkve (ur. H. Jedin, prev. J. Ritig, L. Držić), III-1 (Od crkvenoga ranog srednjeg vijeka do grgurovske reforme), Zagreb 2001, 67.

${ }^{8}$ Р. В. Поповић, Појмовник ирквене историје, Београд 2004, 140-141.
} 
првенство над цариградском патријаршијом и могућност да римски епископ царски центар из Константинопоља може поново да врати у Рим. Данас, ипак, специјалисти умањују политички аспект документа и тврде да то није био официјелни, антивизантијски акт, него део супарништва између Латеранске палате и све више престижне ватиканске Цркве Светог Петра. Овај документ се помиње у многим полемикама између Византинаца и Латина, а у оквиру сложених и вишезначних односа хришћанског Истока и хришћанског Запада. ${ }^{9}$ Без обзира на то да ли је реч о о једном прилично неспретно кривотвореном документу, како мисле једни научници, ${ }^{10}$ или о веома успешном фалсификату, како сматрају други истраживачи, ${ }^{11}$ остаје непобитна чињеница да је „Константинова даровница“ до XIV столећа била веома делотворно оружје у иначе богатом папском арсеналу. ${ }^{12}$

Прва и вероватно једина сумња у аутентичност „Константинове даровнице“ у периоду средњег века потекла је из канцеларије Отона III, немачког краља (9831002) и цара Светог римског царства (996-1002). ${ }^{13}$ Штавише, он се није либио да Римској цркви приговори како је протраћила добро Светог Петра, а да сада то жели да надомести преузимањем добара и права цара. ${ }^{14}$

Занимљиво је напоменути да је својевремено, на размеђу XIII и XIV века, дакле, у време када се није знало да је „Константинова даровница“ фалсификат, највећи италијански песник Данте Алигијери (1265-1321), на свој начин осудио овај документ. Реч је о његовом чувеном спису, трилогији Божанствена комедија, и делу посвећеном паклу, где у XIX певању он каже следеће:

\section{„О Константине, колико је зла донело међу нас не твоје преобраћање, већ што си дао дарове које први богати папа прими у онај час!“‘}

Да је „Константинова даровница“ фалсификат, доказано је у XV веку. Учинили су то најпре филозоф, теолог и математичар Никола Кузански (14011464), ${ }^{16}$ на сабору у Базелу 1433, који је исте године написао дело De Concordantia Catholica, и енглески бискуп и богослов Региналд Пекок (око 1395 - око 1460), ${ }^{17}$ a коначно је 1440. године ренесансни хуманиста Лоренцо Вала (1407-1457) непобитно утврдио да је реч о кривотвореном документу. Он је своје аргументе изнео у делу De

\footnotetext{
9 The Oxford Dictionary of Byzantium (ed. A. P. Kazhdan), vol. I, New York - Oxford 1991, 649 (P. A. Hollingsworth) /у даљем тексту: $O D B /$.

${ }^{10}$ С. Пеинтер, Историја средњег века (284-1500) (прев. Ч. Антић, А. Порчић), Београд - Бања Лука 1997, 89.

${ }^{11}$ Оксфордска историја средњовековне Европе (прир. Џ. Холмс, прев. С. Баранац), Београд - Бања Лука 1998,30 .

${ }^{12}$ С. Пеинтер, Историја средњег века, 147. Такође вид. Р. J. Alexander, The Donation of Constantine at Byzantium and its Earliest Use against the Western Empire, Зборник радова Византолошког института 8-1, 1963, 11-26.

${ }^{13}$ Velika povijest crkve, III-1, 238; DMA, IV, 1984, 258 (J. Van Engen).

${ }^{14}$ Velika povijest crkve, III-1, 238.

15 Данте Алигијери, Пакао (прев. Д. Мраовић), Београд 1998, 136, 114-117.

${ }^{16}$ DMA, IX, 1987, 122-125 (J. Hopkins); A. Kapsalis, False-Donation of Constantine, 92.

${ }^{17}$ DMA, IX, 1987, 482-483 (J. F. Patrouch, Jr.).
} 
falso credita et ementita Constantini Donatione које је написао у Гаети између 2. априла и 25. маја 1440. године. ${ }^{18}$ На историчаре је посебан утисак оставило извођење доказа које је применио Лоренцо Вала, а у којима су видљиви антички утицаји, иначе присутни у историографији епохе. Одмах је дошао до изражаја нови осећај за перспективу прошлости. Италијански хуманиста је своје доказе заснивао на филолошким поставкама, а оне су полазиле од чињенице да се неке речи, односно појмови у тексту „Константинове даровнице“, једноставно нису користили у времену у којем је, како се претпоставља, документ написан. ${ }^{19}$ Притом, не треба губити из вида ни чињеницу да су и Никола Кузански и Лоренцо Вала заправо деловали у име више духовне концепције црквеног суверенитета и мисије.

На другој страни, протестантски реформатори су пригрлили студију Лоренца Вале као сигуран доказ да се папска права ослањају на мноштво неистина. Настављајући оштру линију критицизма, они су наглашавали да „Константинова даровница“ није ништа друго до „чудовишни фалсификат“. ${ }^{20}$ У полемици која се разбуктала, римокатолички интелактуалци су некритички и упорно бранили аутентичност ако не самог документа, а оно барем његовог садржаја. Ова огорчена распра потрајала је чак до XIX века док сва папска права на световни суверенитет нису постала анахрона и сасвим депласирана. Међутим, у научним распрама, све до око 1950. године, сциентистичка озбиљност имала је и примесе конфесионалне пристрасности. $^{21}$

На питање како се ширила истина о „Константиновој даровници“, односно каква је била рецепција студија Николе Кузанског и Лоренца Вале, није лако одговорити. У овом прилогу усмерићемо пажњу на спис Константина Михаиловића, Србина из Островице, који је живео у XV веку и био не само сведок него и активни учесник многих важних историјских догађаја.

Константин Михаиловић је у младићком узрасту, 1455. године, допао турског ропства када су Османлије освојили Ново Брдо. Потом је у служби султана Мехмеда II Освајача (1451-1481) војевао на европским и малоазијским ратиштима: на Пелопонезу, у Влашкој, код Београда, у Босни, око Трапезунта. Као турски заповедник мале тврђаве Звечај на реци Врбасу, у Босни, предао се Угрима и, ступивши у службу краља Матије Корвина (1458-1490), вратио хришћанском свету. Константин Михаиловић је крајем XV столећа написао дело за које се усталио назив Јаничарове успомене. ${ }^{22}$ Његов спис је због актуелне османлијске опасности био веома популаран, па је током следећа два века често преписиван и превођен. До нас су допрли унеколико различити рукописи на чешком и пољском, али се аутограф, дакле, рукопис изашао из пера самог аутора, за који се претпоставља да је био на

\footnotetext{
${ }^{18}$ Р. В. Поповић, Појмовник ирквене историје, 140-141; A. Kapsalis, False-Donation of Constantine, 92.

${ }^{19}$ Оксфордска историја средњовековне Европе, 271-272.

${ }^{20} D M A$, IV, 1984, 259 (J. Van Engen).

${ }^{21} D M A$, IV, 1984, 257-258 (J. Van Engen).

22 За основне податке о животу и делу Константина Михаиловића из Островице вид. М. Кашанин, Српска къижевност у средњем веку, Београд 1975, 476-488; ODB, II, 1147-1148 (S. C. Franklin); Ђ. Живановић, Живот и дело Константина Михаиловића из Островице, Београд 2006, 1-221 као и радове наведене у напоменама које следе.
} 
српском, нажалост, није сачувао. ${ }^{23}$ Тако је ово дело на својеврстан начин наставило да живи авантуристички живот свога творца. До сада је објављено неколико издања списа Константина Михаиловића, ${ }^{24}$ као и преводи и коментари на главне светске језике: енглески, ${ }^{25}$ немачки, ${ }^{26}$ руски. ${ }^{27}$ Реч је, нема сумње, о вишеструко драгоценом историјском извору. ${ }^{28}$ Библиографија о спису Јаничарове успомене или Турска хроника, како се још назива у литератури, веома је богата и разуђена. ${ }^{29}$

У свом делу Константин Михаиловић из Островице у XVIII поглављу помиње императора Константина Великог. Српски јаничар бележи следеће: „Римски цареви су од давнина владали читавим светом од исхода до запада сунца, док није дошао цар Константин Велики. Он уступи Рим светоме оцу папи Силвестру [подвукао Р. Р.], а сам крену у арбанашку земљу ка једноме месту званом Драч; саградивши га, није му се свидело да ту остаје, него крену у Грчку, јер је и сам био Грк, ка месту које је називано Бизант и сазида знаменити град. Све оне красоте које су у Риму биле наредио је да се ту начине и извео је са собом сву римску силу, одведавши седам господара који су у то време владали Римом... “30

\footnotetext{
${ }^{23}$ Н. Радојчић, Српско или страно дело?, Летопис Матице српске 386, 1960, 427-434.

${ }^{24}$ Ми смо користили издање које је приредио Ђ. Живановић, Константин Михаиловић из Островице, Јаничарове успомене или Турска хроника, Споменик Српске академије наука 107, Одељење друштвених наука, Нова серија 9, Београд 1959, 3-72.

${ }^{25}$ Konstantin Mihailović, Memoirs of a Janissary (translated by B. Stoltz, historical commentary and notes by S. Soucek), Michigan Slavic Translations 3, Ann Arbor 1975.

${ }^{26}$ Memoiren eines Janitscharen oder Turkische Chronik (eingeleitet und übersetzt von R. Lachmann, kommentiert von C.-P. Haase, R. Lachmann, G. Prinzing), Slavische Geschichtsschreiber 8, Graz-Wien-Köln 1975 .

27 Записки яничара, написаньл Константином Михайловичем из Островицы (введение, перевод и коментарии А. И. Рогова), Памятники средневековой истории народов Центральной и Восточной Европы, Москва 1978.

${ }^{28}$ G. Prinzing, Zur historischen Relevanz der "Memoiren eines Janitscharen oder turkischen Chronik" des Konstantin Mihailović aus Ostrovica (mélanges Ivan Dujčev), Paris 1979, 373-384.

${ }^{29}$ На пример, вид.: С. Ћирковић, Идеја светског ияартва код Константина из Островице, Зборник радова Византолошког института 7, 1961, 141-145; Ђ. Живановић, Константин Јаничар и српска народна традищија, Прилози за књижевност, језик, историју и фолклор 42, 1976, 66-85; Ђ. Живановић, Константин Михаиловић из Островице. Поводом неких нових радова, Зборник Матице српске за књижевност и језик 24, 1976, 33-59; А. Данти, Старо и ново о Турској хроници, Зборник Матице српске за књижевност и језик 26, 1978, 89-97; Г. Јовановић, Старосрпска антропонимија у „Јаничаровим успоменама“ или „Турској хроници“ Константина Михаиловића из Островице (на основу најстаријег пољског и чешког рукописа из XVI века, Зборник са Шесте југословенске ономастичке конференције, Доњи Милановац, 9-12. октобар 1985. године, Београд 1987, 597-606; Ђ. Живановић, Константин Михаиловић у Франиуској, Анали Филолошког факултета у Београду 20, 2000, 79-104; Р. Радић, Византијски цареви Јован V Палеолог и Јован VI Кантакузин у делу Константина Михаиловића из Островице, Култура и образовање, Зборник са научног скупа (Бања Лука, 10-11. новембра 2006), Научни скупови, књ. 7, том I, Бања Лука 2006, 257-264; Г. Јовановић, Још о презименима у „Јаничаровим успоменама“ или „Турској хроници“ Константина Михаиловића из Островице, Amoenitates vel lepores philologiae, pod redakcja Romana Laskowskiego - Romana Mazurkiewicza, Krakow 2007, 401-406; Р. Радић. Константин о Константину (Константин Велики у спису Константина Михаиловића из Островице), Свети цар Константин и хришћанство (ур. Д. Бојовић), том I, Међународни научни скуп поводом 1700. годишњице Миланског едикта, 31. мај - 2. јун 2013, Ниш 2013, 623-629.

30 Ђ. Живановић, Јаничарове успомене, 21-22; Константин Михаиловић из Островице, Јаничарове
} 
Из овог одељка се види да Михаиловићу нису биле непознате неке подробности о оснивању Константинопоља, као што је, на пример, чињеница да је нова престоница подигнута на месту древног града Византиона. ${ }^{31}$ Из наведеног одломка се такође види да је Константин Михаиловић био упознат и са једном од многих легенди које су се везивале за Константина Великог, а које сежу дубоко у IV век. Према њој је, као што је већ речено, Константин Велики био крштен у Риму, а крштење је обавио папа Силвестар пошто је цара претходно излечио од лепре. Касније је у вези с тим настао и лажни документ тзв. „Константинова даровница (Constitutum Constantini)“ који је имао циљ да ојача моћ римског епископа. ${ }^{32}$ Истина, српски јаничар је легенду сажео у свега неколико речи - „Он [Константин Велики] уступи Рим светоме оцу папи Силвестру“ - али је то урадио на начин који не оставља сумњу да му је била позната читава приповест.

На другој страни, упадљиво је да Константин Михаиловић очито није знао да је легенда коју наводи језгровито, али и свеобухватно, у међувремену сасвим оспорена и дискредитована. Учињено је то отприлике у време када се српски јаничар родио - на свет је дошао око 1435. године - али је очигледно да му је то остало непознато и у раздобљу када је писао своје дело на размеђу XIV и XV века (1497-1501), ${ }^{33}$ дакле неколико деценија касније. Међутим, никако не би требало да изненађује Михаиловићева „необавештеност“, а када то кажемо, на уму имамо најмање три једноставне чињенице. Прва се односи на укупно оновремено стање комуникација и спор проток научних новина, поготово уколико су оне биле тако деликатне и револуционарне као што је сензационално „откриће“ Лоренца Вале. Друга чињеница се тиче социјалног статуса српског јаничара који је био далеко од повлашћених интелектуалних кругова Западне Европе друге половине XV столећа који су, евентуално, могли да буду упућени у откриће ученог италијанског хуманисте. И, на трећем месту, није без значаја ни околност да је Константин Михаиловић последња десетлећа живота провео у римокатоличком хришћанском свету у који је научна истина о „Константиновој даровници“ свакако тешко могла да продре.

Извори и литература:

Извори:

Данте Алигијери, Пакао (прев. Д. Мраовић), Београд 1998.

Живановић, Ђ., Константин Михаиловић из Островице, Јаничарове успомене или Турска хроника, Споменик Српске академије наука 107, Одељење друштвених наука, Нова серија 9, Београд 1959.

de Leo, P., Il Constitutum Constantini: Compilazione agiografica del sec. VIII, vol 1, Reggio

успомене или турска хроника (прев. Ђ. Живановић), Стара српска књижевност у 24 књиге, књ. 15, Београд 1986, 102.

${ }^{31}$ Г. Острогорски, Историја Византије, Београд 1959 (репринт 1998), 64-65.

${ }^{32}$ DMA, IV, 1984, 257-259 (J. Van Engen).

${ }^{33}$ Д. Богдановић, Историја старе српске књижевности, Београд 1980, 237-240. 
Calabria 1974.

Furhman, B. H., Das Constitutum Constantini, Monumenta Germaniae Historica. Fontes Iuris Germanici Antiqui 10, Hanover 1968.

\section{Литература:}

Alexander, P. J., The Donation of Constantine at Byzantium and its Earliest Use against the Western Empire, Зборник радова Византолошког института 8-1, 1963, 11-26.

Богдановић, Д., Историја старе српске књижевности, Београд 1980.

Velika povijest crkve (ur. H. Jedin, prev. V. Bajsić), II (Crkva Carstva poslije Konstanina Velikog), Zagreb 1995.

Velika povijest crkve (ur. H. Jedin, prev. J. Ritig, L. Držić), III-1 (Od crkvenoga ranog srednjeg vijeka do grgurovske reforme), Zagreb 2001.

Gutberlet, B. I., 50 najvećih laži i legendi svetske istorije (prev. D. Jokić), Beograd 2008.

Дагрон, Ж., Цар и првосвештеник: студија о византијском „цезаропапизму“ (прев. В. Тријић), Београд 2001.

Данти, А., Старо и ново о Турској хроници, Зборник Матице српске за књижевност и језик 26, 1978, 89-97.

Dictionary of the Middle Ages (ed. J. R. Strayer), I-XIII, New York 1982-1989.

Живановић, Ђ., Константин Јаничар и српска народна традииија, Прилози за књижевност, језик, историју и фолклор 42, 1976, 66-85.

Живановић, Ђ., Константин Михаиловић из Островице. Поводом неких нових радова, Зборник Матице српске за књижевност и језик 24, 1976, 33-59.

Живановић, Ђ., Константин Михаиловић у Франиуској, Анали Филолошког факултета у Београду 20, 2000, 79-104.

Живановић, Ђ., Живот и дело Константина Михаиловића из Островиие, Београд 2006.

Записки яничара, написаны Константином Михайловичем из Островицы (введение, перевод и коментарии А. И. Рогова), Москва 1978.

Јовановић, Г., Старосрпска антропонимија у „Јаничаровим успоменама“ или „Турској хроници“" Константина Михаиловића из Островище (на основу најстаријег пољског и чешког рукописа из XVI века, Зборник са Шесте југословенске ономастичке конференције, Доњи Милановац, 9-12. октобар 1985. године, Београд 597-606.

Јовановић, Г., Јом о презименима у „Јаничаровим успоменама“ или „Турској хроници“ Константина Михаиловића из Островице, Amoenitates vel lepores philologiae, pod redakcja Romana Laskowskiego - Romana Mazurkiewicza, Krakow 2007, 401-406.

Kapsalis, A., The False-Donation of Constantine, Свети цар Константин и хришћанство (ур. Д. Бојовић), том I, Међународни научни скуп поводом 1700. годишњице Миланског едикта, 31. мај - 2. јун 2013. године, Ниш 2013, 91-107.

Кашанин, М., Српска књижевност у средњем веку, Београд 1975.

Konstantin Mihailović, Memoirs of a Janissary (transl. B. Stoltz, historical commentary and notes by S. Soucek), Michigan Slavic Translations 3, Ann Arbor 1975.

Константин Михаиловић из Островице, Јаничарове успомене или турска хроника (прир. Ђ. Живановић), Стара српска књижевност у 24 књиге, књ. 15, Београд 1986.

Memoiren eines Janitscharen oder Turkische Chronik (übersetzt R. Lachmann, kommentiert von C.P. Haase, R. Lachmann, G. Prinzing), Slavische Geschichtsschreiber 8, Graz-Wien-Köln 1975.

Оксфордска историја средњовековне Европе (прир. Џ. Холмс, прев. С. Баранац), Београд Бања Лука 1998.

Острогорски, Г., Историја Византије, Београд 1959 (репринт 1998). 
Пеинтер, С., Историја средњег века (284-1500) (прев. Ч. Антић, А. Порчић), Београд - Бања Лука 1997.

Поповић, В. Р., Појмовник ирквене историје, Београд 2004.

Prinzing, G., Zur historischen Relevanz der "Memoiren eines Janitscharen oder turkischen Chronik” des Konstantin Mihailović aus Ostrovica (mélanges Ivan Dujčev), Paris 1979, 373-384.

Радић, Р., Византијски цареви Јован V Палеолог и Јован VI Кантакузин у делу Константина Михаиловића из Островище, Култура и образовање, Зборник са научног скупа (Бања Лука, 10-11. новембра 2006), Научни скупови, књ. 7, том I, Бања Лука 2006, 257264.

Радић, Р., Константин о Константину (Константин Велики у спису Константина Михаиловића из Островице), Свети цар Константин и хришћанство (ур. Д. Бојовић), том I, Међународни научни скуп поводом 1700. годишњице Миланског едикта, 31. мај - 2. јун 2013, Ниш 2013, 623-629.

Радојчић, Н., Српско или страно дело?, Летопис Матице српске 386, 1960, 427-434.

The Oxford Dictionary of Byzantium (ed. A. P. Kazhdan), vol. I-III, New York - Oxford 1991.

Ћирковић, С., Идеја светског иарства код Константина из Островице, Зборник радова Византолошког института 7, 1961, 141-145. 


\title{
DID KONSTANTIN MIHAILOVIĆ FROM OSTROVICA KNEW THAT THE ,DONATION OF CONSTANTINE” (CONSTITUTUM CONSTANTINI) WAS A FORGERY?
}

\begin{abstract}
Summary
The work of Konstantin Mihailović from Ostrovica, Serbian janissary from the $15^{\text {th }}$ century, mentions that Constantine the Great "conceded Rome to Holy Father, Pope Sylvester." This actually refers to a legend dating from the $5^{\text {th }}$ century according to which the High Priest of Rome supposedly had converted, baptized and miraculously healed the Emperor. In gratitude, Constantine the Great gave many privileges and gifts to the High Priest of Rome. Based on this legend, during the second half of the $8^{\text {th }}$ century, and most certainly before 770, a document known as "Donation of Constantine (Constitutum Constantini)" was created, according to which, the Pope has been supposedly given, by the first Christian Emperor, the rule over Rome, Italy, and the whole of Western Europe. In 1440s Nicholas of Cusa and Lorenzo Valla proved that without any doubt this document was a forgery. It is obvious that Konstantin Mihailović, who has written his work at the turn of $15^{\text {th }}$ and $16^{\text {th }}$ century, could not had known that the story about Constantine the Great and Pope Sylvester had been proved in the meantime to be a forgery.
\end{abstract}

Keyword: Constantine the Great, popery, forgery, Donation of Constantine (Constitutum Constantini), Konstantin Mihailović, legend 